\title{
Neurogenesis in adult human brain after hemorrhage and ischemic stroke
}

\author{
Tomasz Stępień ${ }^{1}$, Sylwia Tarka², Dominik Chutorański ${ }^{1}$, Paulina Felczak $^{1}$, Albert Acewicz ${ }^{1}$, \\ Teresa Wierzba-Bobrowicz ${ }^{1}$ \\ ${ }^{1}$ Department of Neuropathology, Institute of Psychiatry and Neurology, Warsaw, Poland, ${ }^{2}$ Departament of Forensic Medicine, \\ Medical University of Warsaw, Poland
}

\begin{abstract}
Introduction: Adult neurogenesis includes proliferation and differentiation of progenitor cells as well as their migration and maturation. In the adult human brain, two neurogenic regions, the hippocampal dentate gyrus (DG) and the subventricular zone (SVZ) of lateral ventricles, have been identified. In the dentate gyrus, three types of transcriptionally active cells and in the subventricular zone, four types of transcriptionally active cells, including GFAP-positive neural stem cells (NSCS), have been differentiated.

Material and methods: The aim of the study was to identify and compare density of neurogenic cells between two study groups of patients ( 7 men, 7 women, mean age $70 \pm 6.03$ ) with ischemic stroke and with hemorrhage (6 men, 2 women, mean age $64.75 \pm 12.23$ ) and the control group of patients (6 men, 2 women, mean age 64 \pm 10.95$)$ free of neuropathologic changes who died suddenly within less than $10 \mathrm{~min}$.

Results: In both groups, in the hippocampal dentate gyrus and in the subventricular zone of lateral ventricles, the presence of single GFAP-positive neural stem cells and the transcriptionally active cells labelled with phosphorylated histone $\mathrm{H}_{\text {Ser-10 }}$ ( $\mathrm{p}$-Histone $\mathrm{H} 3_{\text {Ser-10 }}$ )/neural progenitor cells (NPCs), was observed. The quantitative analysis of cells with $p$-Histone $\mathrm{H}_{\text {Ser-10 }}$ expression in the hippocampal DG revealed significant differences between the hemorrhage and control groups $(p=0.001$, test $t)$. However, in the SVZ, it showed a statistically significant decrease in the density of transcriptionally active cells in the group of patients with ischemic stroke ( $p=0.001$, test $t)$. A distinct decrease in the density of transcriptionally active cells, proportional to the length of the patients' hospitalization, was observed. Conclusions: Hypoxia belongs to pathomechanic factors responsible for ischemic stroke, which can induce neurogenesis. However, hypoxia along with ischemia and other factors implicated in ischemic stroke, such as the patient's age or duration of ischemia can have a decisive influence on the decrease in the density of transcriptionally active cells in this pathologic process.
\end{abstract}

Key words: adult neurogenesis, ischemic stroke, $p$-histone $\mathrm{H}_{\text {Ser-10. }}$.

\section{Introduction}

Neurogenesis is the process by which new neurons are generated. It includes proliferation and differentiation of progenitor cells as well as their migration and maturation. Initially it was thought that neurogenesis occurs only during embryonic and perinatal stages in mammals. The first direct evidence of the occurrence of the neurogenic process also in the adult human brain was announced in 1998. Ericsson revealed the generation of new neurons in the granular layer of the hippocampal dentate gyrus (DG) throughout the human life [10]. In

\section{Communicating author}

Tomasz Stępień, PhD, Department of Neuropathology, Institute of Psychiatry and Neurology, Sobieskiego 9, 02-957 Warsaw, Poland, phone: +4822 4582786, e-mail: stepientom@gmail.com 
the adult human brain, two locations of adult neurogenesis, the dentate gyrus (DG) and the subventricular zone (SVZ), have been identified [5,22]. Newborn neurons migrate from the SVZ towards the olfactory bulb (OB). The fate of newborn neurons in the DG is strictly determined topographically and they do not show a tendency to migrate towards the brain neocortical areas. They only participate in the constant supplementation of the pool of new granule cells in the dentate. In the DG three types of transcriptionally active cells have been identified. They are glia-like neural stem cells (NSCs, type-I cells), cells without processes (NSCs, progenitor cells, type-II cells) and neuroblasts $[3,8]$. In the SVZ three types of transcriptionally active cells have been distinguished, namely GFAP-positive neural stem cells (NSCs, type-B1 cells), progenitor cells (NSCs, type-C cells) and neuroblasts (type-A cells) [20].

Cells with an expression of astrocyte-like acidic filaments in the dentate gyrus generate new neurons [25]. Neural stem cells (NSCs) are probably contained within the lineage: "neuroepithelium-radial glia-astrocytes" [1]. This hypothesis is particularly appealing to astrocytes in hippocampal dentate gyrus, because their origin from radial glia has been shown in the developing primate brain [9]. Generation of new neurons and the stages of their maturation are determined by the appearance of specific proteins. An analysis of the protein markers facilitates the identification of neurogenesis phases. Markers of early neurogenesis phases comprise DCX (microtubule-associated protein expressed during neuronal migration) and NeuN (neuronal nuclear antigen) that labels migrating neuroblasts and immature neurons as well as GFAP (glial fibrillary antigen protein) that labels neural stem cells $[11,27]$. Phosphorylated histone $\mathrm{H} 3_{\text {Ser-10 }}$ (p-Histone $\mathrm{H} 3_{\text {Ser-10 }}$ ) is more precise and contrary to DCX, its expression occurs only in newborn neurons (neuronal progenitor cells, NPCs) [23]. Phosphorylation of $\mathrm{N}$-terminal domain of histone $\mathrm{H} 3$ in position Ser-10 and/or Ser-28 destabilizes chromatin, directly preceding replication and transcription $[6,7,17]$.

The aim of our study was to identify transcriptionally active cells and perform a quantitative analysis of neurogenesis cell density as well as to compare three groups of patients with ischemic stroke and with hemorrhage and the control group.

Hypertension, cerebrovascular and cardiovascular diseases are the major causes of ischemic and hemorrhage stroke. Myocardial ischemia and hypoxia are responsible for the loss of neuronal and glial cells, leading to functional impairments and cognitive deficits. Hypoxia belongs to factors that induce neurogenesis. Therefore, an analysis of the involvement of transcriptionally active cells may play a key role in the development of therapeutical procedures $[15,16,19]$.

\section{Material and methods}

The study material was collected from the archives of the First Polish Brain Bank at the Institute of Psychiatry and Neurology, Warsaw, Poland. It comprised two structures - the hippocampal dentate gyrus (DG) and the subventricular zone (SVZ) of the lateral ventricles. The first study group was composed of the brains derived from the patients ( 7 men, 7 women, mean age $70 \pm 6.03$ ) with diagnosed ischemic stroke without focal secondary hemorrhagic transformation. The duration of their hospitalization ranged from $8 \mathrm{~h}$ to 78 days after the occurrence of the ischemic episode. Ischemic changes were located in the left hemisphere in 6 cases, the right hemisphere in 3 cases and in both hemispheres in 5 cases.

The second study group was composed of the brains derived from the patients ( 6 men, 2 women, mean age $64.75 \pm 12.23$ ) with hemorrhage. The length of their hospitalization ranged from $9 \mathrm{~h}$ to 22 days after the occurrence of hemorrhage. In brains derived from 6 patients with intracerebral hemorrhage (ICH) we observed blood in the ventricular system and/or damage of the basal ganglia.

The control group of brains had no significant neuropathological lesions. They were derived from the patients ( 6 men, 2 women, mean age $64 \pm 10.95$ ) whose death occurred suddenly (within less than $10 \mathrm{~min})$.

\section{Immunohistochemistry}

The study material, embedded in paraffin, was cut serially at $5 \mu \mathrm{m}$ slices on the rotary microtone (Leica) into silane-coated glass slides (Silan Sigma A36648), deparaffinized in xylene $3 \times 10 \mathrm{~min}$, hydrated in an ethyl alcohol series, $100 \%, 96 \%$ and $70 \%$ for $10 \mathrm{~min}$ and rinsed in distilled water for $10 \mathrm{~min}$. Epitopes were exposed to temperature of $100^{\circ} \mathrm{C} 3 \times 5$ min in citrate buffer ( $\mathrm{pH} \mathrm{6.0)}$, cooled at room temperature for $10 \mathrm{~min}$ and rinsed in distilled water for $10 \mathrm{~min}$. These were followed by blocking of endogenous peroxidase with $0.3 \%$ TRIS $+\mathrm{H}_{2} \mathrm{O}_{2}$ (TrisBase T1503, pH 7.4-7.6) for $10 \mathrm{~min}$ and rinsed in TRIS for 10 min and blocked with $2.5 \%$ normal horse 
serum (Vector PK-7200) for $1 \mathrm{~h}$. Specimens were incubated with GFAP antibody (1 : 700) (MCA 9733 $\mathrm{G}-1$, Bio-RAD) or with $\mathrm{p}$-Histone antibody $\mathrm{H}_{\text {Ser-10 }}$ (1 : 50) (sc-8656-R, Santa Cruz Biotechnology) for 50 min in $2 \%$ normal horse serum. Then rinsing in TRIS for minimum 40 min took place, incubation with chromogen DAB (Sigma, D5637-SG) for 0-3 min. Rinsing again in distilled water for $10 \mathrm{~min}$, dehydration for 10 min in two ethyl alcohols, $96 \%$ and $100 \%$, respectively, rinsing in xylene $2 \times 10 \mathrm{~min}$ and sizing of Histokitt specimens (MaeFour 1025/500).

\section{Quantitative analysis}

The quantitative analysis was performed using the Cellsens software. Determined cells were counted in two structures, the hippocampal dentate gyrus (DG) and the subventricular zone (SVZ) of lateral ventricles.

\section{Statistical analysis}

The results were analyzed with use of STATISTICA 12 software.

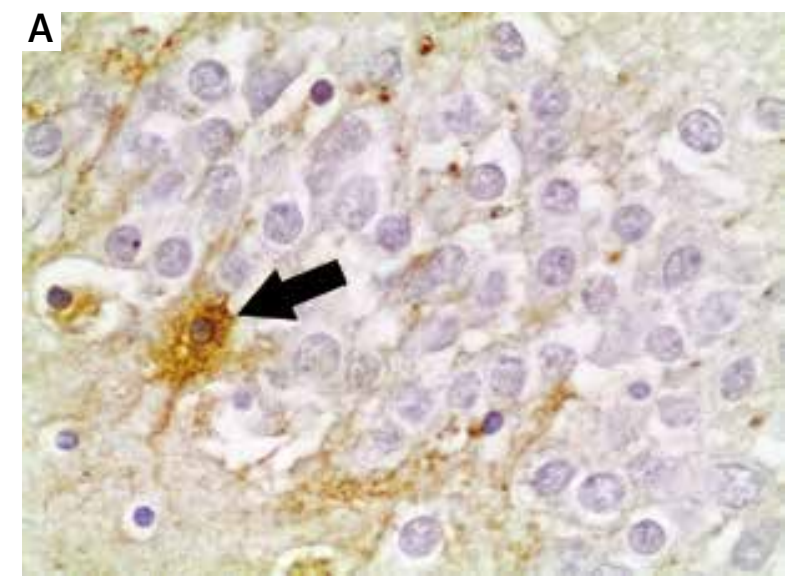

Fig. 1. A) Control group. Dentate gyrus. GFAPpositive neural stem cell with short processes (NSCs, arrow). Immunolabeling with GFAP antibody. Magnification $\times 400$. B) Ischemic stroke. GFAP-positive neural stem cells without processes (NSCs, arrow). Immunolabeling with GFAP antibody. Magnification $\times 400$. C) Hemorrhage. GFAP-positive neural stem cells without processes (NSCs, arrow). Immunolabeling with GFAP antibody. Magnification $\times 400$.

\section{Results}

In all the three groups the presence of single GFAP-positive neural stem cells and the presence of transcriptionally active cells, labelled with $\mathrm{p}$-Histone $\mathrm{H} 3_{\text {Ser-10 }}$, were observed in both the hippocampal dentate gyrus and the subventricular zone. In the control group, GFAP-positive oval cell bodies with visible ample cytoplasm and processes were observed in the DG (Fig. $1 A-C$ ) and in the SVZ, while in the groups of patients with ischemic stroke and hemorrhage, astroglial processes were generally not observed (Fig. 3A-C).

In all groups, cells positively labelled with $\mathrm{p}$-Histone $\mathrm{H} 3_{\text {Ser-10 }}$ showed in the DG a clear point reaction in round cell nuclei (Fig. 2A-C). Whereas, in the SVZ, positive point reaction with phosphorylated histone $\mathrm{H} 3_{\text {Ser-10 }}$ occurred in more oval or longitudinal nuclei (Fig. 4A-C).

The quantitative analysis of cells with $\mathrm{p}$-Histone $\mathrm{H}_{\text {Ser-10 }}$ expression in the SVZ of lateral ventricles revealed a statistically significant decrease in the
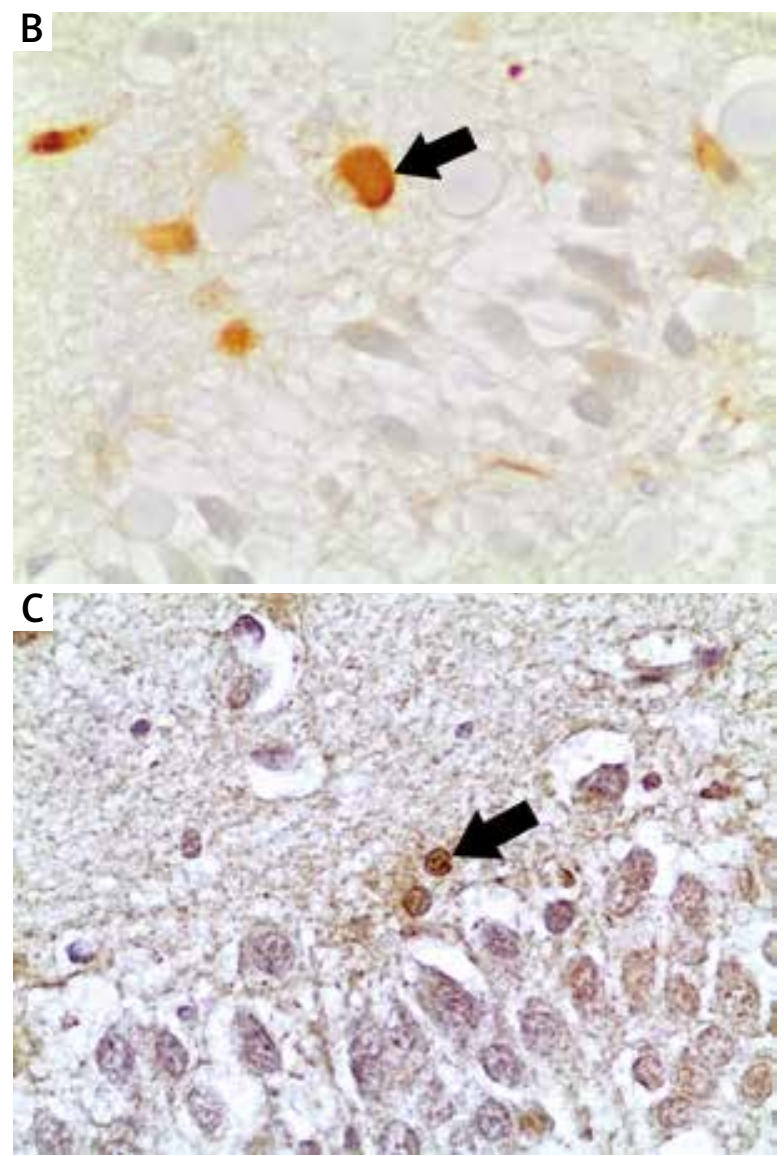


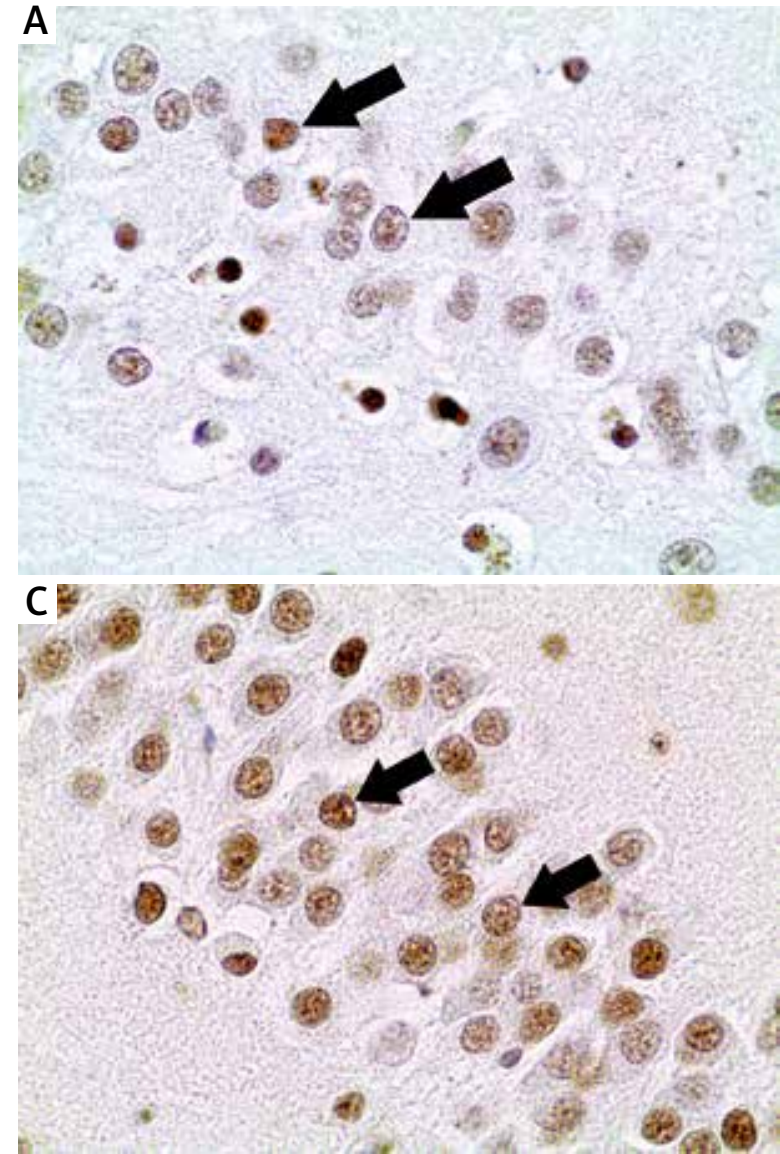

density of transcriptionally active cells in the group of patients with ischemic stroke (442 NPCs $\left./ \mathrm{mm}^{2}\right)$, compared to the control group (856 NPCs/mm²). The same analysis in the hippocampal DG showed significant differences between the hemorrhage (1616 $\mathrm{NPCs} / \mathrm{mm}^{2}$ ) and the control group (424 NPCs $/ \mathrm{mm}^{2}$ ) ( $p \leq 0.001$, test $t$, Fig. 5). No significant differences concerning the density of neural progenitor cells were displayed between ipsilateral and contralateral SVZ hemispheres.

\section{Discussion}

Stroke is one of the most common causes of death and disability of people over 40 years old. Fast symptom recognition can protect against severe consequences, however, we can do nothing if neurons are already damaged. The research has shown that transplantation of NPCs into the brain has improved the neurobehavioral function of subjects in an animal model of intracerebral hemorrhage (ICH) [14].

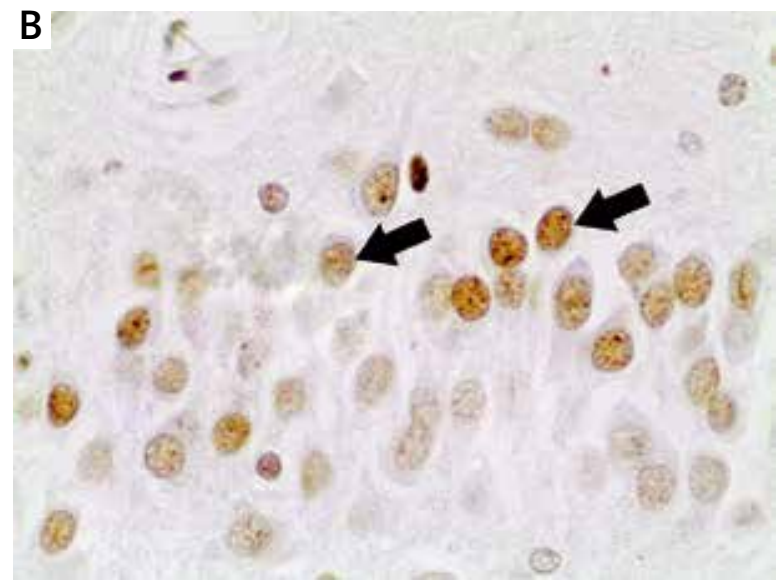

Fig. 2. A) Control group. Dentate gyrus. p-Histone

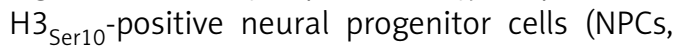
arrows). Immunolabeling with $\mathrm{p}$-Histone $\mathrm{H}_{\text {Ser1 } 1}$ antibody. Magnification $\times 400$. B) Ischemic stroke. Dentate gyrus. p-Histone $\mathrm{H}_{\text {Ser10 }}$-positive neural progenitor cells (NPCs, arrows). Immunolabeling with $\mathrm{p}$-Histone $\mathrm{H} 3_{\text {Ser10 }}$ antibody. Magnification $\times 400$. C) Hemorrhage. Dentate gyrus. p-Histone $\mathrm{H}_{\text {Ser10 }}$-positive neural progenitor cells (NPCs, arrows). Immunolabeling with p-Histone $\mathrm{H}_{\text {Ser10 }}$ antibody. Magnification $\times 400$.

Ischemic stroke occurs when blood vessels become clogged with atheromatous plaque or atheroembolism and it is one of the most frequent causes of death or disability among older people. Except for thrombectomy and thrombolytic therapy within the first few hours after ischemia onset, other therapeutic methods for preventing loss of neurons and glial cells, leading to functional disorders, have not as yet been developed. The process of adult neurogenesis supplementing the pool of neurons and neuroglia cells (astroglia, oligodendroglia) in the damaged brain could become an expected predictor of the injured brain repair and functional recovery.

Our study carried out in both the hippocampal dentate gyrus (DG) and the subventricular zone (SVZ) in the study groups showed the presence of GFAP-positive neural stem cells and the presence of cells labelled with $\mathrm{p}$-Histone $\mathrm{H}_{\text {Ser-10 }}$ transcriptionally active cells of neurogenesis.

The increase in proliferation and migration of progenitor cells towards damaged sites has also been 


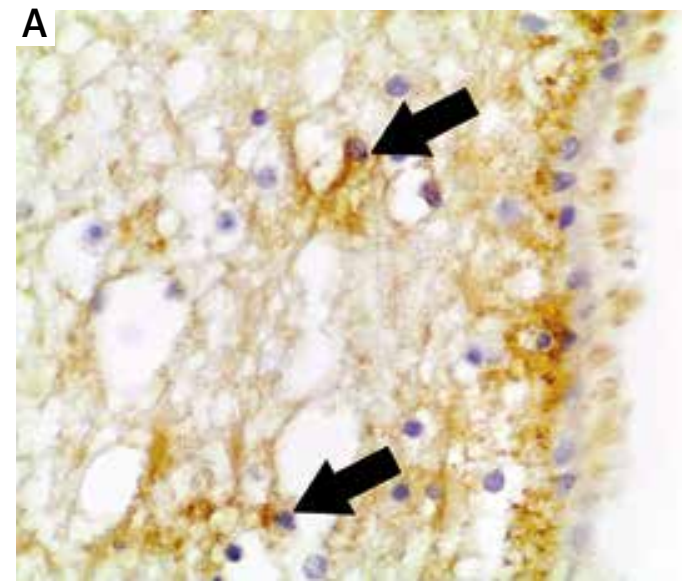

Fig. 3. A) Control group. Subventricular zone (SVZ). GFAP-positive neural stem cells (NSCs, arrows). Immunolabeling with GFAP antibody. Magnification $\times 400$. B) Ischemic stroke. Subventricular zone (SVZ). GFAP-positive neural stem cells (NSCs, arrow). Immunolabeling with GFAP antibody. Magnification $\times 400$. C) Hemorrhage. Subventricular zone (SVZ). GFAP-positive neural stem cells (NSCS, arrow). Immunolabeling with GFAP antibody. Magnification $\times 400$.

observed in focal ischemia and hypoxia [2,31,32]. However, stroke-induced neurogenesis is limited [32]. The quantitative analysis of cells with p-Histone $\mathrm{H} 3_{\text {Ser-10 }}$ expression in the hippocampal dentate gyrus reveal statistically significant differences between the group of patients with hemorrhage stroke and the control group. The quantitative analysis of cells with $\mathrm{p}$-Histone $\mathrm{H} 3_{\text {Ser-10 }}$ expression in the subventricular zone revealed a statistically significant decrease in the density of neural progenitor cells $(p \leq 0.001$, test $t$ ), which suggests the predominance of factors that inhibit the cell division in the process of neurogenesis in patients with ischemic stroke. The patients' age (mean age 70 years \pm 6.033 ) could be one of the unquestionable inhibiting modulators, the age in which the concentration of growth factors decreases. There is strong evidence in humans that hippocampal neurogenesis is reduced across the lifespan [13].

There are many molecular candidates for regulating neurogenesis, including the growth factors.

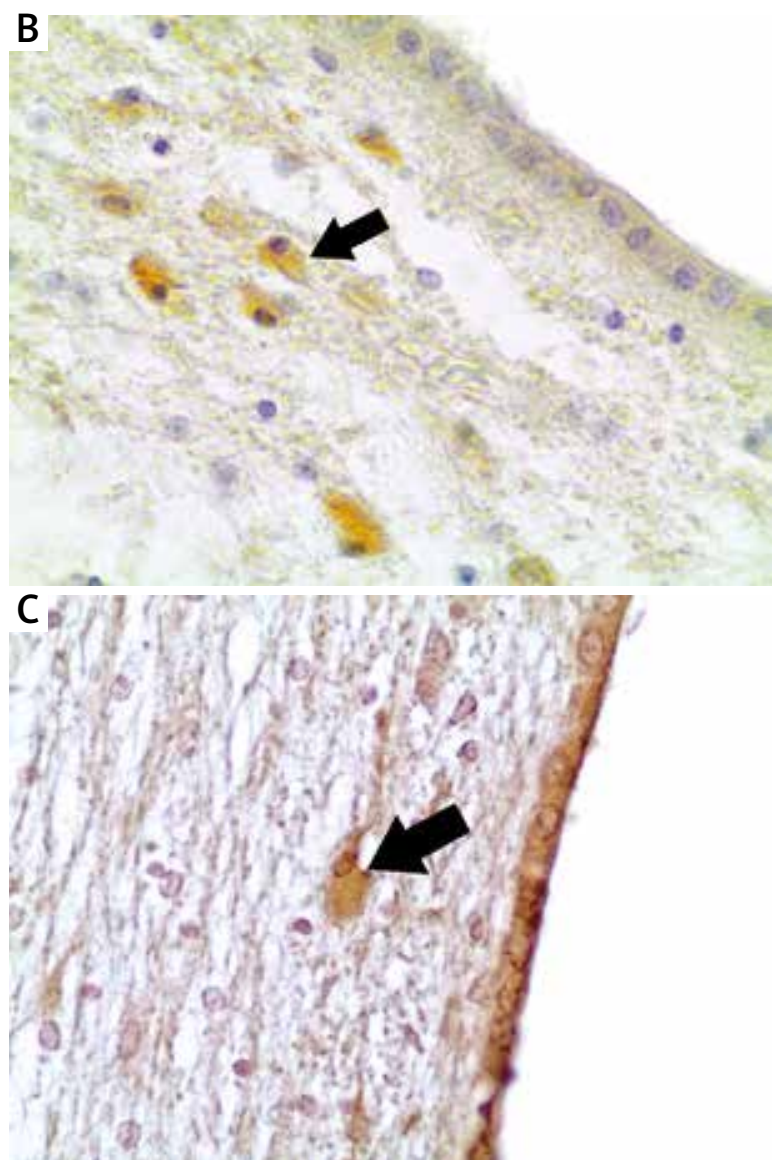

Brain-derived neurotrophic factor (BDNF) whose decrease has a significant impact on the diminished pool of newborn neurons may serve as an example [33]. Disorder of the hypothalamic-pituitary-adrenal (HPA) axis able to increase the cortisol concentration and to reduce neurogenesis is another age-related neurogenesis inhibitor [18]. An evident decrease in the density of transcriptionally active cells, proportional to the length of the patients' hospitalization, inevitably indicating one of the pathogenic factors that inhibits neurogenesis, as well as hypertension medications were also observed [29].

Some studies have suggested that hemorrhage induced neurogenesis, but the majority of the newborn cells did not survive more than 3 weeks due to apoptosis [21]. Our results indicate that intracerebral hemorrhage induced significant proliferation of neural progenitor cells only in dentate gyrus.

We did not observe inducing of neurogenesis in the subventricular zone. It is likely that this observation was associated with the location of cerebral 

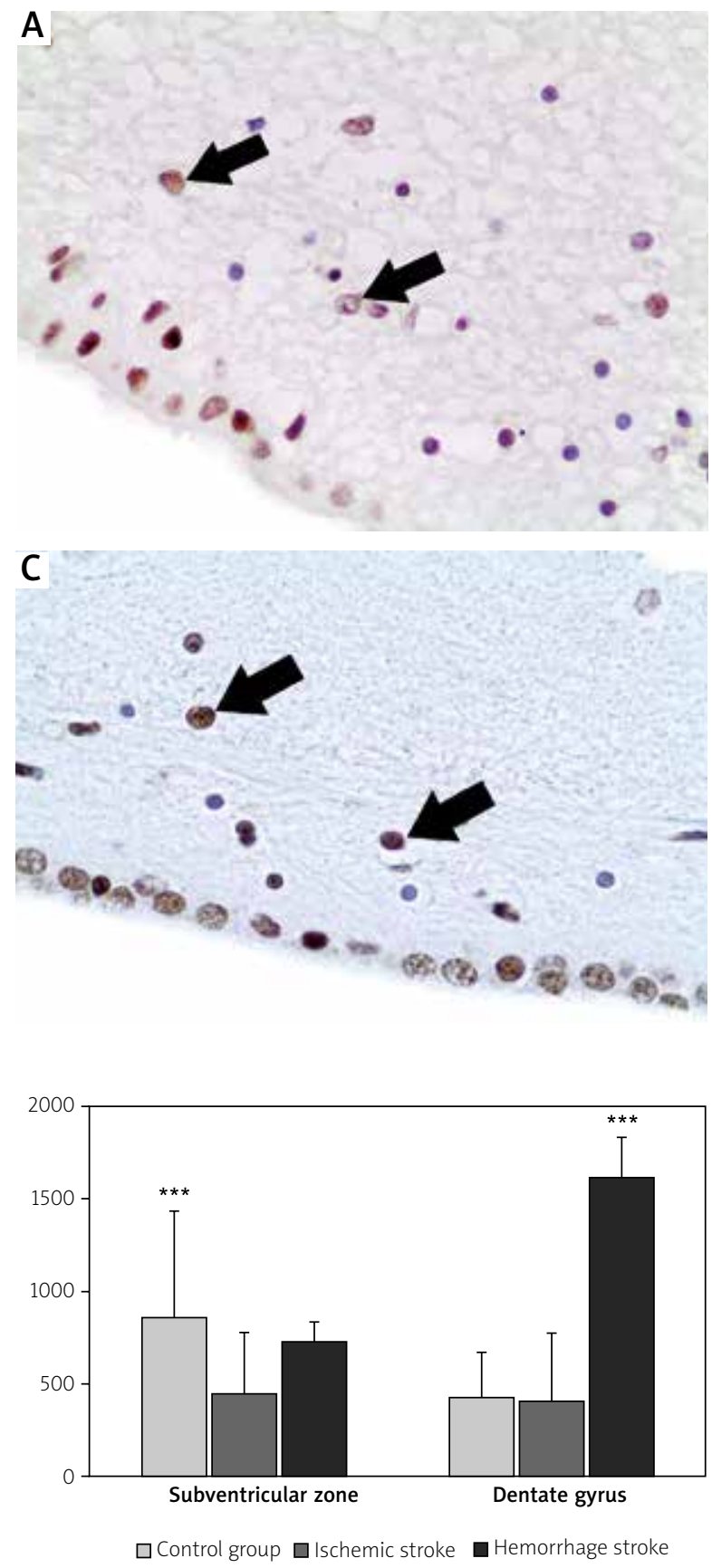

Fig. 5. Density of $\mathrm{p}$-Histone $\mathrm{H}_{\text {Ser10 }}$-positive neural progenitor cells (NPCS) in dentate gyrus and subventricular zone in control and ischemic stroke groups. ${ }^{* \star *} p \leq 0.001$.

ischemic foci. Our study material included 3 cases where necrotic foci also slightly embraced a part of temporal lobes, while in other cases they were primarily located in frontal lobes and remaining cere-

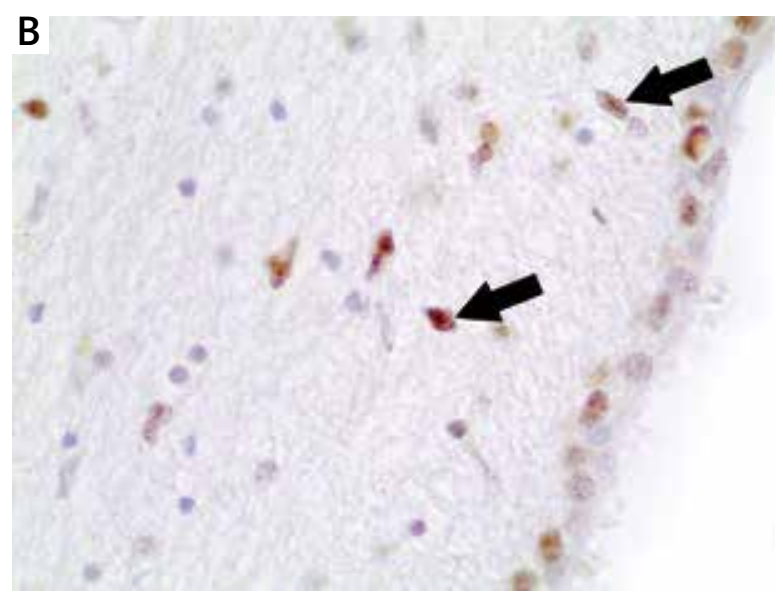

Fig. 4. A) Control group. Subventricular zone (SVZ). p-Histone $\mathrm{H}_{\text {Ser10 }}$-positive neural progenitor cells (NPCS, arrows). Immunolabeling with $\mathrm{p}$-Histone $\mathrm{H}_{\text {Ser10 }}$ antibody. Magnification $\times 400$. B) Ischemic stroke. Subventricular zone (SVZ). p-Histone $\mathrm{H}_{\text {Ser10 }}$-positive neural progenitor cells (NPCs, arrows). Immunolabeling with p-Histone $\mathrm{H}_{\text {Ser10 }}$ antibody. Magnification $\times 400$. C) Hemorrhage. Subventricular zone (SVZ). p-Histone $\mathrm{H}_{3}{ }_{\mathrm{Ser} 10}$-positive neural progenitor cells (NPCs, arrows). Immunolabeling with p-Histone $\mathrm{H}_{3}{ }_{\text {Ser10 }}$ antibody. Magnification $\times 400$.

bral structures. In addition to hypoxia in intracerebral hemorrhage $(\mathrm{ICH})$, there is also the destructive effect of extravasated blood and the effect of mass induced by it. Almost all patients in the hemorrhage group had an extravasated blood in the ventricular system.

In contrast to ischemic stroke, the number of cells lost after hemorrhage is not large, arguing that cell loss is less likely to provide the signal for increased neurogenesis. One possibility is that neurogenesis increases after hemorrhage in response to increased intracranial pressure, which could be detectable at sites, such as SVZ or DG, that are remote from the lesion. Although the effect of increased intracranial pressure on adult neurogenesis has not been examined directly, neurogenesis is enhanced in experimental models of traumatic brain injury [30], which also elevates intracranial pressure [24]. The functional significance of injury-induced neurogenesis remains unclear, but neurogenesis may contribute to brain repair and functional recovery, either through cell replacement or by indirect mechanisms. Some 
findings indicate that the inflammatory process evoked by ICH may increase neurogenesis [28].

However, the latest research suggests that the neurogenesis in dentate gyrus (DG) from fetal development to adulthood a marked decrease, and does not continue, or is extremely rare in adult humans [26]. Similar observations were made by examining the stem/progenitor cells in the heart, liver, kidney and progenitor cells from bone marrow during cardiovascular, cerebral stroke, acute kidney injury and other damage, caused an increase in quality of stem/progenitor cells [12]. A vast number of factors able to modulate the process of neurogenesis have been described. Trophic growth factors (BDNF, FGF, VEGF, TGF, VEGF), serotonin and antidepressants may exert their influence on the growth rate of cell division through affecting specific receptors $[4,16]$.

The identification and elimination of adverse factors affecting the generation of newborn neurons and neuroglial cells in the process of neurogenesis, ischemic stroke and hemorrhage could greatly contribute to the development of new therapeutic methods.

\section{Acknowledgements}

The study was supported by the Institute of Psychiatry and Neurology statutory fund No. 501-07118021. This work is supported by the "Digital Brain - digital collection of the Institute of Psychiatry and Neurology" (Project No. POPC.02.03.01-00.0042/18). The authors are very grateful to the First Polish Brain Bank at the Institute of Psychiatry and Neurology, Warsaw, Poland. Special thanks for Ewa Taracha.

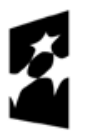

European

Funds Digital Poland

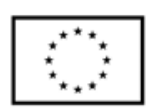

\section{Disclosure}

The authors report no conflict of interest.

\section{References}

1. Alvarez-Buylla A, García-Verdugo JM, Tramontin AD. A unified hypothesis on the lineage of neural stem cells. Nat Rev Neurosci 2001; 2: 287-293.

2. Arvidsson A, Collin T, Kirik D, Kokaia Z, Lindvall O. Neuronal replacement from endogenous precursors in the adult brain after stroke. Nat Med 2002; 8: 963-970.
3. Attardo A, Fabel K, Krebs J, Haubensak W, Huttner WB, Kempermann G. Tis21 expression marks not only populations of neurogenic precursor cells but also new postmitotic neurons in adult hippocampal neurogenesis. Cereb Cortex 2010; 20: 304-314.

4. Bath KG, Lee FS. Neurotrophic factor control of adult SVZ neurogenesis. Dev Neurobiol 2010; 70: 339-349.

5. Brown JP, Couillard-Després S, Cooper-Kuhn CM, Winkler J, Aigner L, Kuhn HG. Transient expression of doublecortin during adult neurogenesis. J Comp Neurol 2003; 467: 1-10.

6. Cano E, Hazzalin CA, Kardalinou E, Buckle RS, Mahadevan LC. Neither ERK nor JNK/SAPK MAP kinase subtypes are essential for histone H3/HMG-14 phosphorylation or c-fos and c-jun induction. J Cell Sci 1995; 108 (Pt 11): 3599-3609.

7. Chadee DN, Hendzel MJ, Tylipski CP, Allis CD, Bazett-Jones DP, Wright JA, Davie JR. Increased Ser-10 phosphorylation of histone $\mathrm{H} 3$ in mitogen-stimulated and oncogene-transformed mouse fibroblasts. J Biol Chem 1999; 274: 24914-2420.

8. Duan X, Kang E, Liu CY, Ming GL, Song H. Development of neural stem cell in the adult brain. Curr Opin Neurobiol 2008; 18 : 108-115.

9. Eckenhoff MF, Rakic P. Radial organization of the hippocampal dentate gyrus: a Golgy, ultrastructural, and immunocitochemical analysis in the developing rhesus monkey. J Comp Neurol 1989; 223: 1-21.

10. Eriksson PS, Perfilieva E, Björk-Eriksson T, Alborn AM, NordborgC, Peterson DA, Gage FH. Neurogenesis in the adult human hippocampus. Nat Med 1998; 4: 1313-1317.

11. Gleeson JG, Lin PT, Flanagan LA, Walsh CA. Doublecortin is a microtubule-associated protein and is expressed widely by migrating neurons. Neuron 1999; 23: 257-271.

12. Gójska-Grymajło A, Zieliński M, Gąsecki D, Kowalczyk K, Kwarciany M, Seroczyńska B, Nyka WM. CD271+, CXCR7+, CXCR4+, and CD133+ Stem/Progenitor Cells and Clinical Characteristics of Acute Ischemic Stroke Patients. Neuromolecular Med 2018; doi: 10.1007/s12017-018-8494-x.

13. Knoth R, Singec I, Ditter M, Pantazis G, Capetian P, Meyer RP, Horvat V, Volk B, Kempermann G. Murine features of neurogenesis in the human hippocampus across the lifespan from 0 to 100 years. PLoS One 2010; 5: e8809.

14. Lee HJ, Park IH, Kim HJ, Kim SU. Human neural stem cells overexpressing glial cell line-derived neurotrophic factor in experimental cerebral hemorrhage. Gene Ther 2009; 16: 1066-1076.

15. Liu J, Solway K, Messing RO, Sharp FR. Increased neurogenesis in the dentate gyrus after transient global ischemia in gerbils. J Neurosci 1998; 18: 7768-7778.

16. Macas J, Nern C, Plate KH, Momma S. Increased generation of neuronal progenitors after ischemic injury in the aged adult human forebrain. J Neurosci 2006; 26: 13114-13119.

17. Mahadevan LC, Willis AC, Barratt MJ. Rapid histone H3 phosphorylation in response to growth factors, phorbol esters, okadaic acid, and protein synthesis inhibitors. Cell 1991; 65: 775-783.

18. Nagalski A, Kiersztan A. Physiology and molecular mechanism of glucocorticoid action. Postepy Hig Med Dosw (Online) 2010; 64: 133-145 [In Polish].

19. Ohira K, Furuta T, Hioki H, Nakamura KC, Kuramoto E, Tanaka Y, Funatsu N, Shimizu K, Oishi T, Hayashi M, Miyakawa T, Kaneko T, 
Nakamura S. Ischemia-induced neurogenesis of neocortical layer 1 progenitor cells. Nat Neurosci 2010; 13: 173-179.

20. Okano H, Sawamoto K. Neural stem cells: involvement in adult neurogenesis and CNS repair. Philos Trans R Soc Lond B Biol Sci 2008; 363: 2111-2122.

21. Otero L, Zurita M, Bonilla C, Rico MA, Aguayo C, Rodriguez A, Vaquero J. Endogenous neurogenesis after intracerebral hemorrhage. Histol Histopathol 2012; 27: 303-315.

22. Pluta R, Bogucka-Kocka A, Ułamek-Kozioł M, Furmaga-Jabłońska W, Januszewski S, Brzozowska J, Jabłoński M, Kocki J. Neurogenesis and neuroprotection in postischemic brain neurodegeneration with Alzheimer phenotype: is there a role for curcumin? Folia Neuropathol 2015; 53: 89-99.

23. Rodríguez JJ, Jones VC, Tabuchi M, Allan SM, Knight EM, LaFerla FM, Oddo S, Verkhratsky A. Impaired adult neurogenesis in the dentate gyrus of a triple transgenic mouse model of Alz heimer's disease. PLoS One 2008; 3: e2935.

24. Shen J, Xie L, Mao X, Zhou Y, Zhan R, Greenberg DA, Jin K. Neurogenesis after primary intracerebral hemorrhage in adult human brain. J Cereb Blood Flow Metab 2008; 28: 1460-1468.

25. Seri B, García-Verdugo JM, McEwen BS, Alvarez-Buylla A. Astrocytes give rise to new neurons in the adult mammalian hippocampus. J Neurosci 2001; 21: 7153-7160.

26. Sorrells SF, Paredes MF, Cebrian-Silla A, Sandoval K, Qi D, Kelley KW, James D, Mayer S, Chang J, Auguste KI, Chang EF, Gutierrez AJ, Kriegstein AR, Mathern GW, Oldham MC, Huang EJ, Garcia-Verdugo JM, Yang Z, Alvarez-Buylla A. Human hippocampal neurogenesis drops sharply in children to undetectable levels in adults. Nature 2018; 555: 377-381.

27. Tanaka R, Yamashiro K, Mochizuki H, Cho N, Onodera M, Mizuno $\mathrm{Y}$, Urabe T. Neurogenesis after transient global ischemia in the adult hippocampus visualized by improved retroviral vector. Stroke 2004; 35: 1454-1459.

28. Tang MM, Lin WJ, Zhang JT, Zhao YW, Li YC. Exogenous FGF2 reverses depressive-like behaviors and restores the suppressed FGF2-ERK1/2 signaling and the impaired hippocampal neurogenesis induced by neuroinflammation. Brain Behav Immun 2017; 66: 322-331.

29. Trejo JL, Carro E, Torres-Aleman I. Circulating insulin-like growth factor I mediates exercise-induced increases in the number of new neurons in the adult hippocampus. J Neurosci 2001; 21: 1628-1634.

30. Urrea C, Castellanos DA, Sagen J, Tsoulfas P, Bramlett HM, Dietrich WD. Widespread cellular proliferation and focal neurogenesis after traumatic brain injury in the rat. Restor Neurol Neurosci 2007; 25: 65-76.

31. Zhang R, Zhang L, Zhang Z, Wang Y, Lu M, Lapointe M, Chopp M. A nitric oxide donor induces neurogenesis and reduces functional deficits after stroke in rats. Ann Neurol 2001; 50: 602-611.

32. Zhang R, Zhang Z, Chopp M. Function of neural stem cells in ischemic brain repair processes. J Cereb Blood Flow Metab 2016; 36: 2034-2043.

33. Zigova T, Pencea V, Wiegand SJ, Luskin MB. Intraventricular administration of BDNF increases the number of newly generated neurons in the adult olfactory bulb. Mol Cell Neurosci 1998; 11: 234-245. 